\title{
Trends in adolescent overweight and obesity in the Nordic countries
}

\author{
Susanna Kautiainen \\ Tampere School of Public Health, University of Tampere, Finland
}

\section{Abstract}

The prevalence of adolescent overweight and obesity has been increasing in most parts of the world during the past few decades. However, data from the Nordic countries have so far been scarce. This overview aims to pull together existing information on secular trends in adolescent overweight and obesity in the Nordic countries. In general, the trends over time have been uniform throughout the Nordic countries, with a steady increase in the prevalence of adolescent overweight and obesity, and an increased right-sided skewness of the body mass index distribution. Continuous monitoring of these trends and studies examining the causes of these trends are needed in order to develop sound strategies to prevent obesity.

Keywords: Denmark; Finland; Iceland; Norway; obesity; Sweden

Received: 13 Sep. 2004; Revised: 14 Dec. 2004; Accepted: 5 Jan. 2005

\section{Introduction}

As the recent report of the International Obesity Task Force (IOTF) to the World Health Organization (WHO) describes, adolescent overweight and obesity are unequally distributed between countries and populations (1). A range of methods of defining and measuring overweight and obesity in adolescence exists $(1,2)$, which complicates the comparison of the prevalence figures from different studies. However, independently of the method used, the prevalence of adolescent overweight and obesity has been increasing in most parts of the world during the past few decades $(1,3)$.

Obesity is known to be related to acute and chronic health problems $(4,5)$, reduced physical performance (6) and psychosocial problems $(5,7)$. The association between obesity and morbidity is perhaps less evident in adolescence than in adulthood, but in addition to its immediate consequences, adolescent obesity tracks into adulthood (4) and is related to obesity-associated morbidity in later life $(4,8)$. There seem to be critical periods for the development of obesity, adolescence being one of them (9).

Therefore, the increasing trends in the prevalence of adolescent overweight and obesity are a serious threat to public health globally that needs to be further monitored. The most extensive data are from the USA, showing that the prevalence of adolescent overweight has tripled in the past three decades (10) and, moreover, overweight adolescents have been becoming steadily heavier (11). Likewise, many European countries are experiencing high year-on-year increases in prevalence (1). Data from the Nordic countries have so far been scarce. For example, the report of the IOTF to the WHO contains data only from one Finnish study with repeated cross-sectional surveys and two Swedish cross-sectional studies (1).

This paper addresses Nordic trends in adolescent overweight and obesity by reviewing the literature published in indexed journals or gathered from Nordic researchers in this field. Implications for public health and further research are discussed.

\section{Methods}

Literature in the area of epidemiology of paediatric overweight and obesity was reviewed by searching for relevant literature in MEDLINE from the start date of the database (1966) to 16 August 2004. The database search was first performed by using wide terms: "overweight/obesity", "Finland/ Sweden/Norway/Denmark/Iceland" and "limited to age group 0-18 years". Articles were then selected primarily if the main topic was secular trends in paediatric overweight and/or obesity, and the study sample included subjects aged between 12-13 and 18-19 years (which was considered as the age range 
for adolescence in this overview). However, to obtain as extensive picture of the existing data as possible, studies with overweight and obesity as a secondary outcome were also quoted. The search was supplemented by computerized searching in the Medic database for Finnish health sciences and in the SweMed + database for Nordic medical articles, by manual searching of reference lists from the articles identified, as well as by contacting researchers in this field in the other Nordic countries. Studies published only as abstracts, at the time of the search, were not included in the present overview.

Information is presented by country. The focus is primarily on the direction and extent of secular changes in the prevalence of overweight and obesity, and secondly on secular changes in the body mass index (BMI) distribution (mean and percentiles). The diversity of methods to measure overweight and obesity is taken into account. Unless mentioned separately, the term "overweight" also includes obese. If available, information in the tables is presented by country, individual study, age, gender and maximally three time-points (the first, the last and one of the closest to the middle of the whole study period).

\section{Results}

\section{Finland}

The nationally representative Adolescent Health and Lifestyle Survey indicates that the prevalence of overweight [according to the BMI reference by Cole et al. (12)] among 12-, 14-, 16- and 18-yearolds increased 2-3-fold from 1977 to 2003 (Table 1) $(13,14)$. The mean BMI increased over the study period (Table 2). Examination of the entire BMI distribution showed that there were only small or no changes in the lower or middle percentiles, but increasing differences at the upper end of the distribution (Fig. 1).

Similarly, the nationally representative WHO Health Behaviour in School-aged Children Study (HBCS) showed that the prevalence of overweight [defined by the BMI reference by Cole et al. (12)] doubled or tripled among 13- and 15-year-old Finnish adolescents between 1984 and 2002 (Table 1) (15). The mean BMI values increased quite steadily (Table 2). The medians of BMI also increased (Table 2).
A Finnish study carried out in the five university cities and in rural communities in their vicinity found no statistically significant changes in the prevalence of obesity of 12-, 15- or 18-year-olds over the period 1980-1986, based on American BMI criteria (16) (Table 1) (17). However, further analyses from a subsample of the data suggested a one-unit increase in the mean BMI in 15- and 18year-olds during 1980-1992 (Table 2), parallel to increases in skinfold thickness (18).

Adolescents $(n \approx 1100)$ living in four geographical areas in Finland were studied in 1995 as part of international research on European young people's lifestyle and physical activity (19). The authors made comparisons to another sample of adolescents from 1985-1991 ( $n \approx 1200)$, and found that the mean BMI had increased by 0.2 and $0.3 \mathrm{~kg} \mathrm{~m}^{-2}$ in 13- and 15-year-old boys, and by 0.6 and $0.8 \mathrm{~kg}$ $\mathrm{m}^{-2}$ in girls, respectively.

\section{Sweden}

In Sweden, Rasmussen et al. (20) reported a 2.4-fold increase in the prevalence of overweight (BMI $\geq 25$ ), and a 3.5-fold increase in the prevalence of obesity $(\mathrm{BMI} \geq 30)$ among 18 -year-old male military conscripts between 1971 and 1995 (Table 1). Mean BMI values increased by $6.6 \%$ during the same period (Table 2). The right-sided skewness of the BMI distributions increased from 1971 to 1992 , and then decreased until 1995. After adjustment for muscle power, demographic factors and living area, the prevalence of overweight was found to have increased 1.4-fold, and obesity 1.7-fold from 1971 to 1993 (20). An update of the same study showed that the increasing trends continued from 1995 to 1998 , the increase in the prevalence of overweight and obesity from 1971 to 1998 being 2.5- and 4.2-fold, respectively, and that of mean BMI 6.9\% (Tables 1 and 2) (21).

Similarly, a 2-3-fold increase in the prevalence of overweight (BMI $>25$ ) was found among 16-yearold boys and girls in secondary schools in six geographical areas in Sweden from 1974 to 1995 (Table 1) (22). During that period the mean BMI increased by $0.8 \mathrm{~kg} \mathrm{~m}^{-2}$ both in boys and in girls (Table 2).

Ekblom et al. (23) used the BMI criteria by Cole et al. (12) and found that the prevalence of overweight among 10-, 13- and 16-year-olds living in the middle and southern parts of Sweden increased more than 2.5-fold between 1987 (7.6\%) 
Table I. Studies reporting trends in prevalence of adolescent overweight/obesity in the Nordic countries

\begin{tabular}{|c|c|c|c|c|c|c|c|c|c|}
\hline \multirow[b]{2}{*}{$\begin{array}{l}\text { Country } \\
\text { (Reference) }\end{array}$} & \multirow{2}{*}{$\begin{array}{l}\text { Total no. } \\
\text { of time- } \\
\text { points }\end{array}$} & \multirow[b]{2}{*}{$\begin{array}{l}\text { Age } \\
\text { (years) }\end{array}$} & \multirow[b]{2}{*}{ Year } & \multirow[b]{2}{*}{$\begin{array}{l}\text { sample } \\
\text { size }\end{array}$} & \multirow[b]{2}{*}{$\begin{array}{l}\text { Definition of } \\
\text { overweight/obesity (Reference) }\end{array}$} & \multicolumn{2}{|c|}{$\begin{array}{l}\text { Prevalence (\%) } \\
\text { of overweight } \\
\text { (including obesity) }\end{array}$} & \multicolumn{2}{|c|}{$\begin{array}{l}\text { Prevalence (\%) } \\
\text { of obesity }\end{array}$} \\
\hline & & & & & & Boys & Girls & Boys & Girls \\
\hline \multicolumn{10}{|l|}{ Finland } \\
\hline \multirow[t]{12}{*}{$(13,14)$} & 13 & 12 & 1977 & 689 & BMI (self-reported weight and height) (12) & 8.2 & 6.9 & 2.0 & 0.9 \\
\hline & & & 1991 & 786 & & 14.6 & 10.2 & 3.2 & 1.6 \\
\hline & & & 2003 & 725 & & 21.5 & 13.7 & 3.1 & 1.9 \\
\hline & & 14 & 1977 & 697 & & 6.3 & 4.2 & 1.5 & 0.0 \\
\hline & & & 1991 & 2468 & & 12.0 & 9.1 & 1.4 & 1.0 \\
\hline & & & 2003 & 2269 & & 19.1 & 12.0 & 4.0 & 2.3 \\
\hline & & 16 & 1977 & 715 & & 7.7 & 3.9 & 0.8 & 0.3 \\
\hline & & & 1991 & 2247 & & 11.6 & 8.0 & 2.0 & 1.0 \\
\hline & & & 2003 & 2253 & & 20.2 & 10.7 & 4.2 & 2.1 \\
\hline & & 18 & 1977 & 663 & & 6.5 & 1.2 & 0.0 & 0.3 \\
\hline & & & 1991 & 1970 & & 13.8 & 8.6 & 1.9 & 1.9 \\
\hline & & & 2003 & 1342 & & 17.6 & 11.3 & 3.4 & 2.6 \\
\hline \multirow[t]{6}{*}{ (15) } & 5 & 13 & 1984 & 1091 & BMI (self-reported weight and height) (12) & 7 & 6 & I & 0 \\
\hline & & & 1994 & 1226 & & 14 & 11 & I & I \\
\hline & & & 2002 & 1655 & & 17 & 11 & 4 & 1 \\
\hline & & 15 & 1984 & 1082 & & 8 & 3 & 1 & $<1$ \\
\hline & & & 1994 & 1151 & & 12 & 4 & I & 1 \\
\hline & & & 2002 & 1709 & & 18 & 9 & 3 & 1 \\
\hline \multirow[t]{8}{*}{$(17)$} & 3 & 12 & 1980 & 650 & BMI >90th percentile [US reference $(16)]$ & & & 3.4 & 3.0 \\
\hline & & & 1983 & 568 & & & & 5.8 & 2.9 \\
\hline & & & 1986 & 480 & & & & 6.4 & 2.9 \\
\hline & & 15 & 1980 & 601 & & & & 4.9 & 2.2 \\
\hline & & & 1983 & 538 & & & & 5.2 & 3.5 \\
\hline & & & 1986 & 487 & & & & 5.4 & 4.5 \\
\hline & & 18 & 1980 & 537 & & & & 3.1 & 1.8 \\
\hline & & & 1983 & 438 & & & & 2.5 & 3.4 \\
\hline \multicolumn{7}{|l|}{ Sweden } & & 2.2 & 3.0 \\
\hline \multirow[t]{3}{*}{$(20,21)$} & 12 & 18 & 1971 & 49355 & $\mathrm{BMI} \geq 25$ and $\mathrm{BMI} \geq 30$ & 6.9 & & 0.9 & \\
\hline & & & 1986 & 53444 & & 11.2 & & 1.8 & \\
\hline & & & 1998 & 42352 & & 17.6 & & 3.8 & \\
\hline \multirow[t]{2}{*}{ (22) } & 2 & 16 & 1974 & 394 & $\mathrm{BMI}>25$ & 3 & 3 & & \\
\hline & & & 1995 & 444 & & 7 & 9 & & \\
\hline \multirow[t]{4}{*}{ (23) } & 2 & 13 & 1987 & - & BMI (I2) & - & - & - & - \\
\hline & & & 2001 & 637 & & 19.5 & 19.1 & 6.2 & 2.9 \\
\hline & & 16 & 1987 & - & & - & - & - & - \\
\hline & & & 2001 & 587 & & 18.3 & 17.5 & 3.1 & 3.4 \\
\hline \multirow[t]{2}{*}{ (24) } & 2 & 13 & 1967 & 620 & $\geq 120 \%$ of standard weight for height & & & & \\
\hline & & & 1980 & 270 & & & & & \\
\hline \multicolumn{10}{|l|}{ Norway } \\
\hline (27) & $14^{\mathrm{a}}$ & $\sim 18$ & $1967 / \sim 1985^{b}$ & 32546 & $\mathrm{BMI} \geq 25$ and $\mathrm{BMI} \geq 30$ & $\sim 11$ & & $<2$ & \\
\hline Denmark & & & $1980 / \sim 1998^{b}$ & 25153 & & $\sim 17$ & & $\sim 4$ & \\
\hline$(3 I)$ & $32^{a}$ & $\sim 19$ & 1943 & 883 & $\mathrm{BMI} \geq 25.7$ and $\mathrm{BMI} \geq 3 \mathrm{I} .0$ & 2.7 & & 0.8 & \\
\hline & & & $1972-74$ & 551 & & 9.9 & & 7.0 & \\
\hline (32) & 20 & $\sim 19$ & $1939 / \sim 1957^{\mathrm{b}}$ & 897 & $\mathrm{BMI} \geq 30$ & & & 0.3 & \\
\hline & & & $1948 / \sim 1966^{b}$ & 1190 & & & & 0.3 & \\
\hline & & & $1958 / \sim 1976^{b}$ & 851 & & & & 1.3 & \\
\hline (33) & 16 & $\sim 19$ & $1943-47$ & 160 & $\mathrm{BMI} \geq 25$ & 5.0 & & & \\
\hline & & & $|960-6|$ & 154 & & 7.8 & & & \\
\hline
\end{tabular}




\begin{tabular}{|c|c|c|c|c|c|c|c|c|c|}
\hline \multirow[b]{2}{*}{$\begin{array}{l}\text { Country } \\
\text { (Reference) }\end{array}$} & \multirow{2}{*}{$\begin{array}{l}\text { Total no. } \\
\text { of time- } \\
\text { points }\end{array}$} & \multirow[b]{2}{*}{$\begin{array}{l}\text { Age } \\
\text { (years) }\end{array}$} & \multirow[b]{2}{*}{ Year } & \multirow[b]{2}{*}{$\begin{array}{l}\text { sample } \\
\text { size }\end{array}$} & \multirow[b]{2}{*}{$\begin{array}{l}\text { Definition of } \\
\text { overweight/obesity (Reference) }\end{array}$} & \multicolumn{2}{|c|}{$\begin{array}{l}\text { Prevalence (\%) } \\
\text { of overweight } \\
\text { (including obesity) }\end{array}$} & \multicolumn{2}{|c|}{$\begin{array}{l}\text { Prevalence (\%) } \\
\text { of obesity }\end{array}$} \\
\hline & & & & & & Boys & Girls & Boys & Girls \\
\hline & & & $1976-77$ & 263 & & 9.5 & & & \\
\hline \multirow[t]{3}{*}{ (34) } & 3 & $\sim 19$ & $1955 / \sim 1973^{b}$ & 6549 & $\mathrm{BMI} \geq 30$ & & & 1.5 & \\
\hline & & & $1965 / \sim 1983^{b}$ & 6404 & & & & 2.1 & \\
\hline & & & $1973-75 / 1993-94^{b}$ & 4300 & & & & 4.6 & \\
\hline (37) & 2 & $14-16$ & $197 \mid-72$ & - & BMI (I2) & 5.1 & 6.2 & 0.4 & 0.9 \\
\hline \multicolumn{10}{|c|}{ 1996-97 } \\
\hline \multirow[t]{2}{*}{ (38) } & 2 & $15-24$ & 1990 & - & $\mathrm{BMI} \geq 25$ & 9 & 17 & & \\
\hline & & & 2002 & - & & 26 & 15 & & \\
\hline
\end{tabular}

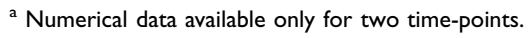

${ }^{\mathrm{b}}$ Born in/measured.

-: Missing information.

and $2001(20.0 \%)$. The means and medians of BMI at each age also showed an increasing trend during the study period (Table 2). However, the changes were not proportionate over the whole BMI distribution, but the greatest increase was found in the higher percentiles of BMI (23).

A nutrition survey of children in a northern Swedish county (Västerbotten) in 1930 was repeated in 1967 and again in 1980 (24). According to that study, the prevalence of overweight (defined as $\geq$ $120 \%$ of standard weight for height) among 13 -yearold adolescents increased 1.6-fold from 1967 to 1980 (Table 1).

According to a study of Stockholm schoolchildren, the BMI of 13-year-olds remained fairly stable for the cohorts born from 1933 to 1963, concerning both mean and median (Table 2) (25).

Using two separate samples corrected mathematically to be comparable, Lindgren and Hauspie (26) found a trend towards a relatively higher BMI for all ages from approximately 10 to 15 years for children born in 1955 and 1967 (Table 2).

\section{Norway}

A study of Norwegian conscripts showed that the prevalence of overweight had increased approximately 1.5-fold from conscripts born in 1967 to those born in 1980 (27). During the same period, prevalence of obesity had roughly doubled (Table 1).
In a study of schoolchildren aged 8-18 years in Oslo from 1920 to 1975 (the gender- and agespecific number of subjects varied between 100 and 3000 depending on the study year), there was a sharp decline in average weight for height during World War II and a rapid subsequent rebound thereafter (28). Except for that, no overall increase in weight for height was observed during the study period. A subsequent update of 8-18-year-old girls living in Oslo (age-specific $n=250-400$ ) concluded that the postwar trend towards lower weights had been reversed from 1975 to 1985, although the weights for height were still below the level from the early postwar period (29).

By comparing the results of the European Youth Heart Study in 2000 with the results from Brundtland et al. (28), Heggebø (30) estimated that weight for height of Oslo adolescents had increased from 1975 to 2000 by approximately $3 \mathrm{~kg}$ and $2 \mathrm{~kg}$ in 15 -year-old boys and girls $(n=350)$, respectively.

\section{Denmark}

In Denmark, data on young men examined at draft boards (mainly 18-22 years old) exist from the 1940s $(31,32)$. According to those data, the prevalence of obesity stayed low and stable until the early 1960s. After that, a steep increase in the prevalence of obesity was observed, which levelled off in the 1970s (Table 1). The mean, median and lower percentiles of the BMI remained almost constant during that period, whereas the upper 
Table 2. Studies reporting trends in means (SD) and medians of body mass index (BMI) of adolescents in the Nordic countries

\begin{tabular}{|c|c|c|c|c|c|c|c|c|}
\hline \multirow{2}{*}{$\begin{array}{l}\text { Country } \\
\text { (Reference) }\end{array}$} & \multirow{2}{*}{$\begin{array}{l}\text { Total no. of } \\
\text { time-points }\end{array}$} & \multirow[b]{2}{*}{ Age (years) } & \multirow[b]{2}{*}{ Year } & \multirow[b]{2}{*}{ Sample size } & \multicolumn{2}{|l|}{ Mean (SD) } & \multicolumn{2}{|c|}{ Median } \\
\hline & & & & & Boys & Girls & Boys & Girls \\
\hline \multicolumn{9}{|l|}{ Finland } \\
\hline \multirow[t]{12}{*}{$(13,14)$} & 13 & 12 & 1977 & 689 & I8.I (2.5) & $18.3(3.0)$ & 17.6 & 17.8 \\
\hline & & & 1991 & 786 & (8.8 (3.0)) & $18.6(3.0)$ & 18.3 & 17.9 \\
\hline & & & 2003 & 725 & $19.3(3.1)$ & $19.0(3.0)$ & 18.6 & 18.6 \\
\hline & & 14 & 1977 & 697 & $19.3(2.5)$ & $19.3(2.2)$ & 18.8 & 19.1 \\
\hline & & & 1991 & 2468 & 20.0 & $19.9(2.8)$ & 19.6 & 19.5 \\
\hline & & & 2003 & 2269 & $20.6(3.5)$ & $20.4(3.4)$ & 19.8 & 19.7 \\
\hline & & 16 & 1977 & 715 & $20.9(2.5)$ & $20.2(2.2)$ & 20.7 & 19.8 \\
\hline & & & 1991 & 2247 & $21.4(2.8)$ & $20.9(2.9)$ & 21.0 & 20.4 \\
\hline & & & 2003 & 2253 & $21.9(3.3)$ & $21.1(3.2)$ & 21.2 & 20.4 \\
\hline & & 18 & 1977 & 663 & $21.7(2.2)$ & $20.4(2.2)$ & 21.3 & 20.2 \\
\hline & & & 1991 & 1970 & $22.3(2.8)$ & $21.3(3.0)$ & 22.0 & 20.8 \\
\hline & & & 2003 & 1342 & 22.6 & 21.4 & 22.0 & 20.7 \\
\hline \multirow[t]{6}{*}{ (15) } & 5 & 13 & 1984 & 1145 & $18.7(2.4)$ & $18.5(2.5)$ & 18.3 & 18.4 \\
\hline & & & 1994 & 1279 & $19.6(2.6)$ & $19.6(2.9)$ & 19.2 & 19.2 \\
\hline & & & 2002 & 1732 & 20.0 & $19.7(3.0)$ & 19.5 & 19.1 \\
\hline & & 15 & 1984 & 1122 & $20.4(2.5)$ & $19.6(2.1)$ & 20.1 & 19.4 \\
\hline & & & 1994 & 1194 & $20.8(2.6)$ & $20.1(2.4)$ & 20.4 & 19.8 \\
\hline & & & 2002 & 1745 & $21.2(3.2)$ & $20.6(2.8)$ & 20.6 & 20.1 \\
\hline \multirow[t]{2}{*}{ (I8) } & 5 & 15,18 & 1980 & 1122 & 20.8 & & & \\
\hline & & & 1986 & 857 & 21.1 & & & \\
\hline \multicolumn{9}{|l|}{ Sweden } \\
\hline \multirow[t]{3}{*}{$(20,21)$} & 12 & 18 & $197 \mid$ & 49355 & $21.1(2.6)$ & & & \\
\hline & & & 1986 & 53444 & 21.9 & & & \\
\hline & & & 1998 & 42352 & 22.5 & & & \\
\hline \multirow[t]{2}{*}{ (22) } & 2 & 16 & 1974 & 394 & $20.2(2.4)$ & $20.5(2.3)$ & 19.9 & 20.1 \\
\hline & & & 1995 & 444 & $21.0(2.5)$ & $21.3(2.6)$ & 20.7 & 21.0 \\
\hline \multirow[t]{4}{*}{ (23) } & 2 & 13 & 1987 & 77 & $19.0(4.3)$ & $18.9(2.0)$ & 18.2 & 18.9 \\
\hline & & & 2001 & 518 & $19.8(3.5)$ & $19.9(3.5)$ & 19.0 & 19.2 \\
\hline & & 16 & 1987 & 360 & $20.7(2.6)$ & $20.6(2.1)$ & 20.3 & 20.2 \\
\hline & & & 2001 & 513 & $21.5(3.0)$ & $21.8(3.1)$ & 21.0 & 21.3 \\
\hline \multirow[t]{3}{*}{ (25) } & 4 & 13 & $1933 / \sim 1946^{b}$ & 1153 & $18.0(2.1)$ & $18.7(2.3)$ & 17.7 & 18.4 \\
\hline & & & $1953 / \sim 1966^{b}$ & 1846 & $18.0(2.4)$ & $18.6(2.7)$ & 17.7 & 18.2 \\
\hline & & & $1963 / \sim 1976^{b}$ & $|45|$ & $17.9(2.3)$ & $18.6(2.6)$ & 17.5 & 18.2 \\
\hline \multirow[t]{6}{*}{ (26) } & 2 & 13 & $1955 / \sim 1968^{b}$ & 738 & $17.8(2.2)$ & $18.2(2.5)$ & & \\
\hline & & & $1967 / \sim 1980^{b}$ & 1075 & $18.2(2.5)$ & $18.7(3.0)$ & & \\
\hline & & 14 & $1955 / \sim 1969^{b}$ & 738 & $18.5(2.3)$ & $18.8(2.4)$ & & \\
\hline & & & $1967 /\left.\sim 198\right|^{b}$ & 977 & $19.3(2.5)$ & $19.9(3.3)$ & & \\
\hline & & 15 & $1955 / \sim 1970^{b}$ & 736 & $19.1(2.3)$ & $19.3(2.4)$ & & \\
\hline & \multicolumn{7}{|c|}{ 100 } & \\
\hline$(3 I)$ & $32^{a}$ & $\sim 19$ & 1943 & 883 & 21.5 & & 21.5 & \\
\hline & & & $1972-74$ & 551 & 21.7 & & 21.3 & \\
\hline$(32)$ & 20 & $\sim 19$ & $1939 / \sim 1957^{b}$ & 897 & & & 21.1 & \\
\hline & & & $1948 / \sim 1966^{b}$ & 1190 & & & 21.3 & \\
\hline & & & $1958 / \sim 1976^{b}$ & 851 & & & 21.3 & \\
\hline (33) & 16 & $\sim 19$ & $1943-47$ & 160 & $21.5(2.0)$ & & & \\
\hline & & & $|960-6|$ & 154 & $21.1(2.4)$ & & & \\
\hline & & & $1976-77$ & 263 & 21.5 & & & \\
\hline (34) & 3 & $\sim 19$ & $1955 / \sim 1974^{b}$ & 6549 & $22.0(2.7)$ & & 21.7 & \\
\hline & & & $1965 / \sim 1984^{b}$ & 6404 & $22.3(2.8)$ & & 22.0 & \\
\hline & & & $1973-75 / 1993-94^{b}$ & 4300 & $23.4(3.5)$ & & 22.8 & \\
\hline (37) & 2 & 13 & $|97|-72$ & 2150 & 18.0 & 18.4 & - & - \\
\hline
\end{tabular}




\begin{tabular}{|c|c|c|c|c|c|c|c|c|}
\hline \multirow{2}{*}{$\begin{array}{l}\text { Country } \\
\text { (Reference) }\end{array}$} & \multirow{2}{*}{$\begin{array}{l}\text { Total no. of } \\
\text { time-points }\end{array}$} & \multirow[b]{2}{*}{ Age (years) } & \multirow[b]{2}{*}{ Year } & \multirow[b]{2}{*}{ Sample size } & \multicolumn{2}{|c|}{ Mean (SD) } & \multicolumn{2}{|c|}{ Median } \\
\hline & & & & & Boys & Girls & Boys & Girls \\
\hline & & & $1996-97$ & 377 & 18.6 & 19.5 & 18.7 & 19.3 \\
\hline & & 14 & $197 \mid-72$ & 2269 & 18.7 & 19.3 & - & - \\
\hline & & & $1996-97$ & 306 & 19.6 & 20.1 & 19.7 & 20.4 \\
\hline & & 15 & $197 \mid-72$ & $2|4|$ & 19.3 & 19.9 & - & - \\
\hline & & & $1996-97$ & 2042 & 20.5 & 21.2 & 20.5 & 21.3 \\
\hline
\end{tabular}

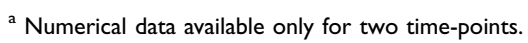

${ }^{\mathrm{b}}$ Born in/measured.

-: Missing information.

part of the distribution showed an increased skewness beginning around 1960 (Table 2) $(32,33)$.

Sørensen et al. (34) studied the Danish conscripts further, examining men born in 1973-1975 (studied in 1993-1994) and comparing the results with two birth cohorts of men born in 1955 and 1965. The prevalence of obesity (BMI $\geq 30 \mathrm{~kg} \mathrm{~m}^{-2}$ ) increased 3 -fold during the whole study period (Table 1). The mean, median and standard deviation of BMI increased during the same time (Table 2), suggesting that an increased skewness of the BMI distribution had taken place at the same time as the shift in the entire distribution.

Changes similar to those of the conscripts were observed among 7-13-year-old boys in Copenhagen between 1937 and 1983 (35). The increase in the prevalence of obesity in children began just after World War II and thus it started in children before it increased in adults. The authors used three different definitions for obesity, corresponding to different degrees of obesity. If defined by the 99.9 th or 99.0th percentile of BMI, the prevalence of obesity increased in the 1950s, levelled off in the 1960s and increased again from the late 1970s. If defined by the 95.0th percentile, a sharp distinct increase in the prevalence of obesity was observed in the late 1940s. The median BMI showed only small fluctuations over the study period, whereas the right-sided skewness of the BMI distribution of the boys increased during the first two decades of the study and levelled off around 1970.

Wedderkopp (36) compared deciles of the ponderal index of 14-16-year-old Danish (Odense area) adolescents $(n=431)$ in 1997-1998 with those of 15-18-year-old adolescents in 1983-1984 from another Danish study. He found that there was both an overall increase in the ponderal index and an increase in the difference between lowest and
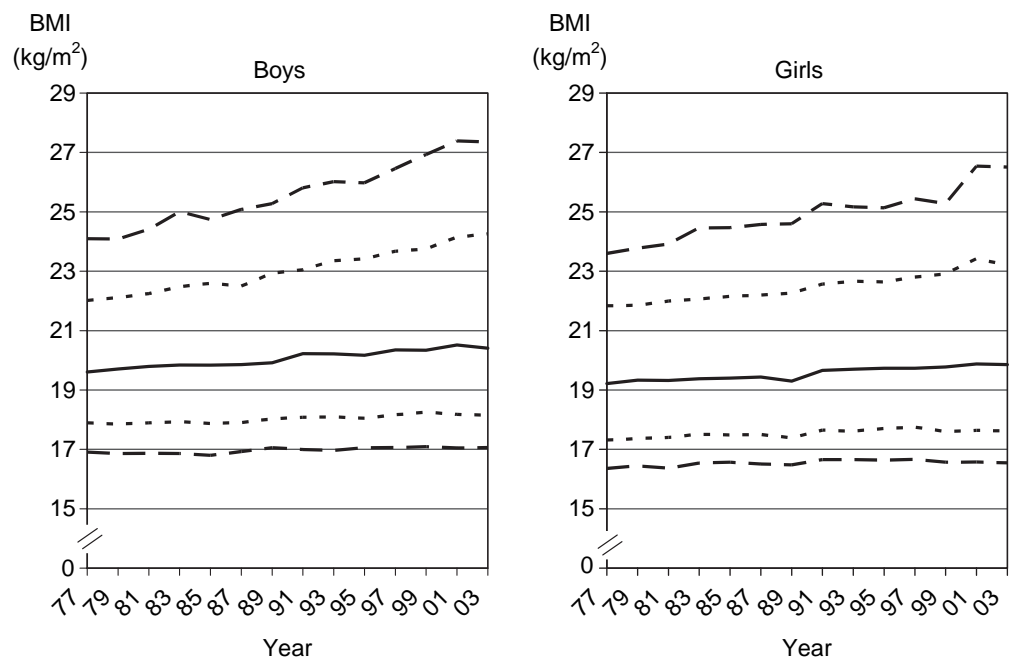

Fig. 1. Age-standardized 5th, 15th, 50th, 85th and 95th percentile curves of body mass index (BMI) for 12-18-year-old boys and girls in 1977-2003 in the Adolescent Health and Lifestyle Survey in Finland. 
highest ponderal index levels during the study period.

Petersen et al. (37) studied BMI distributions based on school health measurements of a nationally representative sample of Danish children who were approximately 14-16 years old during the school year 1996/97. Compared with another Danish study of children in 1971/72, the proportion of overweight [according to the BMI reference by Cole et al. (12)] among 14-16-year-old adolescents increased 3-fold in boys and 2.5-fold in girls (Table 1). The average BMI values were significantly higher than in 1971/72 (Table 2). In particular, the highest BMI percentiles had increased, indicating an increased degree of obesity among the obese.

\section{Iceland}

No trend data specifically on adolescent overweight were found concerning Iceland. According to the national dietary studies run in Iceland in 1990 and 2002, however, the proportion of overweight (BMI $\geq 25 \mathrm{~kg} \mathrm{~m}^{-2}$ ) seems to have stayed stable or even decreased slightly among young women aged 15-24 years, whereas the proportion of overweight young men has almost tripled (38) (Table 1).

\section{Discussion}

\section{Comparison between the Nordic countries}

Based on this overview, the trends over time in the prevalence of adolescent overweight and obesity have been very uniform throughout the Nordic countries. Studies from the most distant time-points are from Denmark, and suggest that there was a decrease related to war, a subsequent rebound and a levelling-off in the increase of prevalence of overweight/obesity in the 1970s (31-33, 35). More recent studies show consistently that the prevalence of adolescent overweight has increased approximately $2-3$-fold since the 1970s or the 1980s in all the Nordic countries with data available. The slight inconsistency between the findings of the two older $(17,18)$ and the two later studies $(13-15)$ from Finland could be explained by the shorter followup, or by the fact that the samples of the older studies were not nationally representative and suffered from moderate non-response in the follow-up. In the only study from Iceland (38), an increase in the prevalence of overweight was observed in adolescent and young adult males but not females. Whether Icelandic adolescent girls are different from girls in the other Nordic countries is hard to say based on one study with only two time-points, beginning only in the 1990, and including older subjects than studies from the other Nordic countries.

Results concerning changes over time in the whole distribution of BMI were quite consistent. According to the older studies, in general, no change in the central parts of the distribution was observed, except for a decline and rebound related to World War II in Norway $(25,28,31-33,35)$. Since the 1970s, the mean BMI has been increasing in all the countries with data available. Concurrently, an increase in the skewness of the BMI distribution has been observed at least in Finland (13), Sweden $(20,23)$ and Denmark (32-35, 37), suggesting that the degree of severity of obesity has increased.

\section{Comparison between the Nordic and other countries} The phenomena of increasing prevalence of overweight and obesity and increasing skewness of the BMI distribution are congruent with results from other countries. The magnitude of the increase in the prevalence has been similar to that in the USA $(10,11)$, even though the prevalence figures are still far below those in the USA: in an international comparison of 13- and 15-year-olds, the US adolescents reported a higher prevalence of overweight than any of the European countries or regions (or Israel) (39). In that same study, Finland belonged to the countries with a significantly higher prevalence of BMI at or above the 85th percentile of the study reference standard, whereas countries with a significantly low prevalence of BMI at or above the 85 th percentile of the study reference standard included Denmark and Sweden (39). At first glance, this does not become evident from the comparable Finnish $(13,15)$ and Swedish (23) studies presented in this overview. However, this contradiction is likely to be due to the fact that the Swedish study used measured data, whereas both of the Finnish studies are based on self-reported weight and height information, which may be prone to reporting errors (40). Within Europe, the highest prevalence levels of childhood and adolescent obesity at present are observed in southern European countries, while northern European countries tend to have a lower prevalence (1).

For US adolescents, the entire BMI distribution shifted upwards from 1976-1980 to 1988-1994 
(41). Concurrently, the right-sided skewness of the distribution has increased (41). In addition to the Nordic countries, the same has also been reported from other European countries, e.g. Spain (42). In other words, not only has the proportion of overweight adolescents increased, but also the overweight adolescents have been becoming more overweight.

\section{Potential explanations}

Reasons for these trends are being chased frantically around the world. Genetic changes cannot have taken place rapidly enough to explain the epidemic increase in the prevalence of overweight and obesity worldwide. Thus, trends in environmental factors affecting energy balance are interesting as potential explanations for the increasing trends in the prevalence of overweight and obesity. The findings of decreasing (43) or stable (18) reported intake of energy and fat since the beginning of the 1980s, and increasing physical activity since the 1980s (43) among Finnish adolescents do not support the theory of poor dietary habits and lack of physical activity behind the increases in the prevalence of overweight and obesity. However, there may be changes in eating patterns, e.g. snacking (44), increased soft drink consumption (45), a decrease in lifestyle activity (e.g. commuting to and from school), as in adults (46), and an increase in sedentary behaviour, e.g. watching television and using computers $(43,47)$. It is also possible that some important factors may be operating early in life rather than at older ages (48).

The potential factors behind the secular trends in overweight and obesity are not necessarily universal (3). However, cross-sectional data on dietary factors (49) and trend data on physical activity (50) in adolescents, as well as sedentary behaviour in adults (51), seem to be similar, at least in Finland, Sweden, Norway and Denmark. There are some differences between the Nordic countries, e.g. in serving school lunch (49), which may be important when planning prevention strategies against obesity in different Nordic countries.

The phenomenon of unequal changes over time in central and extreme parts of the BMI distribution suggests that some of the causes underlying the increase in the prevalence of overweight and obesity may be either (i) specific environmental factors affecting only a subset of the population (differential exposure) or (ii) more general environmental factors to which only a part of the population is vulnerable, because their genetic background (gene-environment interaction) or earlier environmental influences make them particularly susceptible (differential response to the "obesogenic" environment), or (iii) a combination of these (differential exposure and differential response) $(35,41)$.

\section{Critique}

This paper is not a systematic critical review, but aims to offer an overall picture of the time trends in adolescent overweight and obesity in the Nordic countries based on the studies available. In addition to the bias potentially related to the literature search (concerning studies with trends in obesity as a secondary outcome in particular), publication bias should be considered. Some of the studies on national trends may have been published only in the native language/national journals or reports, and may thus be unavailable through a search of indexed journals. However, researchers in the other Nordic countries were contacted in order to reach national publications as well.

Nationally representative Nordic studies on trends in adolescent obesity have so far been scarce. Moreover, few representative cross-sectional studies have been conducted repeatedly using the same methodology. Such studies give a more reliable picture of secular trends than separate cross-sectional studies made on only one occasion. To obtain as complete a picture of the trends as possible, studies concerning conscripts were also included in the overview: although a very small proportion may be examined even beyond the age of 26 years, by far the most conscripts attend the draft board at the age of 18-19 years and are examined shortly afterwards $(27,31-34)$. In spite of the varying age groups and periods covered, all studies reviewed reached pretty similar conclusions.

Most of the studies found measured overweight and obesity by BMI, which has been determined to be an appropriate measure for epidemiological use $(12,52)$. The use of varying reference criteria to define overweight and obesity limits the comparability of the prevalence figures from different studies. However, it does not hinder the comparison of the secular changes in the prevalence, as long as the same reference criteria are used in the subsequent cross-sectional studies. 
The two most recent studies from Finland were based on height and weight data self-reported by the respondent adolescents. When comparing selfreported information with measured anthropometric data, it seems that BMI values based on self-reported height and weight tend to be somewhat underestimated, more so by girls than by boys, and more by overweight than normal weight adolescents, which may lead to an underestimation of the proportions of overweight and obese adolescents in the population (40). However, unless the misreporting has changed over the study period, the possible bias is the same over time and does not affect the time trends observed, in which case selfreports provide a relatively easy way to gather trend data from large population samples.

\section{Implications}

The trends of increasing prevalence of overweight and obesity are of importance as they imply that the increasing burden of chronic diseases associated with obesity will be a reality in the future in the Nordic countries as well as in other countries. The risk of obesity tracking into adulthood is higher with more severe obesity (53), which makes the increased right-sided skewness of the BMI distribution of even more concern. A vicious circle between the time trends in the prevalence of adulthood (51, 54-56) and adolescent (as well as childhood) obesity may be a serious threat in the future, given that adolescent obesity persists into adulthood and that parental obesity is a known risk factor for the development of obesity in a child (57). Prevention has generally been seen as the principal approach for dealing with obesity (1), and should start during childhood and adolescence, when the lifestyle of an individual is taking shape. However, no single strategy for prevention has yet proved to be effective (1). Identifying the factors causing obesity is central in planning prevention and targeting it efficiently. The first step in assessing the causative - and preventive - factors is to monitor trends in obesity in a range of populations (1), including adolescents. However, monitoring the epidemiology of obesity by describing only the proportion of those being obese or only the central part of the relative weight distribution is insufficient $(11,35)$, because those measures could reflect either a general increase in fatness of the whole population or an expression of increased obesity in subgroups of presumably susceptible individuals (58). Therefore, it is impor- tant to monitor the shape of the whole distribution of relative weight.

In conclusion, adolescents in the Nordic countries are experiencing the same "epidemic" of overweight and obesity that is taking place in most parts of the world. Future research needs to continue monitoring the trends in overweight and obesity, and to conduct studies to examine the causes of these trends, in order to develop sound strategies to prevent obesity.

\section{Acknowledgements}

I express my gratitude to Professor Arja Rimpelä and Director Mikael Fogelholm for valuable comments on the manuscript, and to Kristiina Ojala, Finland; Gösta Samuelson and Örjan Ekblom, Sweden; Niels Wedderkopp, Denmark; Liv Grøtvedt, Norway; and Laufey Steingrímsdóttir and Hólmfríður Porgeirsdóttir, Iceland, who helped me with gathering data not indexed in the databases searched.

\section{References}

1. Lobstein T, Baur L, Uauy R. IASO International Obesity Task Force. Obesity in children and young people: a crisis in public health. Obes Rev 2004; 5 Suppl 1: 4-104.

2. Guillaume M. Defining obesity in childhood: current practice. Am J Clin Nutr 1999; 70 Suppl: 126-30S.

3. Kohn M, Booth M. The worldwide epidemic of obesity in adolescents. Adolesc Med 2003; 14: 1-9.

4. Must A, Strauss RS. Risks and consequences of childhood and adolescent obesity. Int J Obes Relat Metab Disord 1999; 23 Suppl 2: S2-11.

5. Must A, Anderson SE. Effects of obesity on morbidity in children and adolescents. Nutr Clin Care 2003; 6: 412.

6. Torok K, Szelenyi Z, Porszasz J, Molnar D. Low physical performance in obese adolescent boys with metabolic syndrome. Int $\mathbf{J}$ Obes Relat Metab Disord 2001; 25: 966-70.

7. Gortmaker SL, Must A, Perrin JM, Sobol AM, Dietz WH. Social and economic consequences of overweight in adolescence and young adulthood. $\mathrm{N}$ Engl $\mathrm{J}$ Med 1993; 329: 1008-12.

8. Must A, Jacques PF, Dallal GE, Bajema CJ, Dietz WH. Long-term morbidity and mortality of overweight adolescents. A follow-up of the Harvard Growth Study of 1922 to 1935. N Engl J Med 1992; 327: 1350-5.

9. Dietz WH. Critical periods in childhood for the development of obesity. Am J Clin Nutr 1994; 59: 955-9.

10. Ritchie LD, Ivey SL, Woodward-Lopez G, Crawford PB. Alarming trends in pediatric overweight in the United States. Soz Praventivmed 2003; 48: 168-77. 
11. Jolliffe D. Extent of overweight among US children and adolescents from 1971 to 2000. Int J Obes Relat Metab Disord 2004; 28: 4-9.

12. Cole TJ, Bellizzi MC, Flegal KM, Dietz WH. Establishing a standard definition for child overweight and obesity worldwide: international survey. BMJ 2000; 320: 1240-3.

13. Kautiainen S, Rimpela A, Vikat A, Virtanen SM. Secular trends in overweight and obesity among Finnish adolescents in 1977-1999. Int J Obes Relat Metab Disord 2002; 26: 544-52.

14. Rimpelä A, Rainio S, Pere L, Saarni L, Kautiainen S, Kaltiala-Heino R, et al. [Adolescent health in Finland in 1977-2003]. Suom Lääkäril 2004; 59: 4229-35. (In Finnish.)

15. Välimaa R, Ojala K. Nuorten paino, laihduttaminen ja painon kokeminen. In: Kannas L, ed. Nuorten terveys ja terveyskäyttäytyminen muutoksessa. Jyväskylä, Finland: WHO-Koululaistutkimus 20 v. (In Finnish.) (in press)

16. Cronk CE, Roche AF. Race- and sex-specific reference data for triceps and subscapular skinfolds and weight/ stature. Am J Clin Nutr 1982; 35: 347-54.

17. Nuutinen EM, Turtinen J, Pokka T, Kuusela V, Dahlstrom S, Viikari J, et al. Obesity in children, adolescents and young adults. Ann Med 1991; 23: 41-6.

18. Porkka KV, Raitakari OT, Leino A, Laitinen S, Rasanen L, Ronnemaa T, et al. Trends in serum lipid levels during 1980-1992 in children and young adults. The Cardiovascular Risk in Young Finns study. Am J Epidemiol 1997; 146: 64-77.

19. Nupponen H, Telama R. [Physical activity and motor fitness as part of the lifestyle of 11-16-year-old European young people]. Jyväskylä, Finland: Department of Physical Education; 1998. (In Finnish.)

20. Rasmussen F, Johansson M, Hansen HO. Trends in overweight and obesity among 18-year-old males in Sweden between 1971 and 1995. Acta Paediatr 1999; 88: 431-7.

21. Rasmussen F, Johansson M. Increase in the prevalence of overweight and obesity from 1995 to 1998 among 18year-old males in Sweden. Acta Paediatr 2000; 89: 8889.

22. Westerstahl M, Barnekow-Bergkvist M, Hedberg G, Jansson E. Secular trends in body dimensions and physical fitness among adolescents in Sweden from 1974 to 1995. Scand J Med Sci Sports 2003; 13: 128-37.

23. Ekblom OB, Oddsson K, Ekblom BT. Prevalence and regional differences in overweight in 2001 and trends in BMI distribution in Swedish children from 1987 to 2001. Scand J Public Health 2004; 32: 257-63.

24. Persson LA, Samuelson G, Sjolin S. Nutrition and health in Swedish children 1930-1980. Three nutrition surveys in a northern Swedish county. Acta Paediatr Scand 1989; 78: 865-72.

25. Cernerud L, Lindgren GW. Secular changes in height and weight of Stockholm schoolchildren born in 1933, 1943, 1953 and 1963. Ann Hum Biol 1991; 18: 497-505.
26. Lindgren GW, Hauspie RC. Heights and weights of Swedish school children born in 1955 and 1967. Ann Hum Biol 1989; 16: 397-406.

27. Bjerkedal T, Beckstrom JR, Brevik JI, Skaden K. [Height, weight and body mass index measured among men born 1967-80]. Tidsskr Nor Laegeforen 2001; 121: 674-7. (In Norwegian.)

28. Brundtland GH, Liestol K, Walloe L. Height, weight and menarcheal age of Oslo schoolchildren during the last 60 years. Ann Hum Biol 1980; 7: 307-22.

29. Liestol K, Rosenberg M. Height, weight and menarcheal age of schoolgirls in Oslo - an update. Ann Hum Biol 1995; 22: 199-205.

30. Heggebø LK. European Youth Heart Study - the Norwegian part. A cross-sectional study of physical activity, cardiorespiratory fitness, obesity and blood pressure in children and youth (Dissertation). Oslo: Department of Sports Medicine, Norwegian University of Sport and Physical Education; 2003.

31. Sonne-Holm S, Sorensen TI. Post-war course of the prevalence of extreme overweight among Danish young men. J Chronic Dis 1977; 30: 351-8.

32. Sorensen TI, Price RA. Secular trends in body mass index among Danish young men. Int J Obes 1990; 14: 411-9.

33. Christensen U, Sonne-Holm S, Sorensen TI. Constant median body mass index of Danish young men, 19431977. Hum Biol 1981; 53: 403-10.

34. Sørensen HT, Sabroe S, Gillman M, Rothman KJ, Madsen KM, Fischer P, et al. Continued increase in prevalence of obesity in Danish young men. Int $\mathrm{J}$ Obes Relat Metab Disord 1997; 21: 712-4.

35. Thomsen BL, Ekstrom CT, Sorensen TI. Development of the obesity epidemic in Denmark: cohort, time and age effects among boys born 1930-1975. Int J Obes Relat Metab Disord 1999; 23: 693-701.

36. Wedderkopp N. Atherosclerotic cardiovascular risk factors in Danish children and adolescents. A community based approach with special reference to physical fitness and obesity (Dissertation). Faculty of Health Sciences, Institute of Sport Science and Clinical Biomechanics, University of Southern Denmark; 2000.

37. Petersen TA, Rasmussen S, Madsen M. [BMI of Danish schoolchildren measured during the periods 1986/19871996/1997 compared to Danish measurement in 1971/ 1972]. Ugeskr Laeger 2002; 164: 5006-10. (In Danish.)

38. [The diet of Icelanders. Dietary survey of the Icelandic Nutrition Council 2002]. (In Icelandic.)

39. Lissau I, Overpeck MD, Ruan WJ, Due P, Holstein BE, Hediger ML, et al. Body mass index and overweight in adolescents in 13 European countries, Israel, and the United States. Arch Pediatr Adolesc Med 2004; 158: $27-$ 33.

40. Crawley HF, Portides G. Self-reported versus measured height, weight and body mass index amongst $16-17$ year old British teenagers. Int $\mathbf{J}$ Obes Relat Metab Disord 1995; 19: 579-84.

41. Flegal KM, Troiano RP. Changes in the distribution of body mass index of adults and children in the US 
population. Int $\mathrm{J}$ Obes Relat Metab Disord 2000; 24 : 807-18.

42. Moreno LA, Sarria A, Fleta J, Rodriguez G, Bueno M. Trends in body mass index and overweight prevalence among children and adolescents in the region of Aragon (Spain) from 1985 to 1995. Int J Obes Relat Metab Disord 2000; 24: 925-31.

43. Fogelholm M. Diet, physical activity and health in Finnish adolescents in the 1990s. Scand J Nutr 1998; 42: $10-2$.

44. Ovaskainen ML, Reinivuo H, Tapanainen H, Männistö S, Pakkala H, Valsta L. [Dietary habits of the Finnish adult population]. Suom Lääkäril 2004; 59: 1525-30. (In Finnish.)

45. Lahti-Koski M, Sirén M. [Nutrition report 2003]. Report No. B4/2004. Helsinki: National Public Health Institute; 2004. (In Finnish.)

46. Fogelholm M, Mannisto S, Vartiainen E, Pietinen P. Determinants of energy balance and overweight in Finland 1982 and 1992. Int J Obes Relat Metab Disord 1996; 20: 1097-104.

47. Niemi I, Pääkkönen H. [Time use changes in Finland through the 1990s]. Helsinki: Statistics Finland; 2001. (In Finnish.)

48. Rolland-Cachera MF, Deheeger M, Bellisle F. Increasing prevalence of obesity among 18-year-old males in Sweden: evidence for early determinants. Acta Paediatr 1999; 88: 365-7.

49. Samuelson G. Dietary habits and nutritional status in adolescents over Europe. An overview of current studies in the Nordic countries. Eur J Clin Nutr 2000; 54 Suppl 1: $\mathrm{S} 21-8$.

50. Westerstahl M, Barnekow-Bergkvist M, Hedberg G, Jansson E. Secular trends in sports: participation and attitudes among adolescents in Sweden from 1974 to 1995. Acta Paediatr 2003; 92: 602-9.

51. Matthiessen J, Andersen NL, Ovesen LF. [The significance of diet and physical activity for the development of obesity in Denmark from 1985 to 1995]. Ugeskr Laeger 2001; 163: 2941-5. (In Danish.)

52. Bellizzi MC, Dietz WH. Workshop on childhood obesity: summary of the discussion. Am J Clin Nutr 1999; 70 Suppl: 173-5S.

53. Guo SS, Roche AF, Chumlea WC, Gardner JD, Siervogel RM. The predictive value of childhood body mass index values for overweight at age $35 \mathrm{y}$. Am J Clin Nutr 1994; 59: 810-9.

54. Lahti-Koski M, Vartiainen E, Mannisto S, Pietinen P. Age, education and occupation as determinants of trends in body mass index in Finland from 1982 to 1997. Int J Obes Relat Metab Disord 2000; 24: 1669-76.

55. Sundquist K, Qvist J, Johansson SE, Sundquist J. Increasing trends of obesity in Sweden between 1996/ 97 and 2000/01. Int J Obes Relat Metab Disord 2004; 28 : 254-61.

56. Midthjell K, Kruger O, Holmen J, Tverdal A, Claudi T, Bjorndal A, et al. Rapid changes in the prevalence of obesity and known diabetes in an adult Norwegian population. The Nord-Trondelag Health Surveys: 19841986 and 1995-1997. Diabetes Care 1999; 22: 1813-20.

57. Whitaker RC, Wright JA, Pepe MS, Seidel KD, Dietz WH. Predicting obesity in young adulthood from childhood and parental obesity. N Engl J Med 1997; 337: 869-73.

58. Guillaume M, Lissau I. Epidemiology. In: Burniat W, Cole T, Lissau I, Poskitt E, eds. Child and adolescent obesity. Causes and consequences, prevention and management. Cambridge: Press Syndicate of the University of Cambridge; 2002. p. 28-49.

Susanna Kautiainen, MD

Tampere School of Public Health

Fl-330| 4 University of Tampere

Finland

E-mail: susanna.kautiainen@uta.fi 